\title{
Inter-functional Coordination to Co-create Value Within Integrated Value Chains for Competitive Supply Chain
}

\author{
Umer Mukhtar \\ School of Business and Economics, \\ University of Management and Technology, Pakistan \\ Email: umer-mukhtar@live.com (Corresponding Author) \\ Tashfeen Mahmood Azhar \\ School of Business and Economics, \\ University of Management and Technology, Pakistan \\ Email: tashfeen@umt.edu.pk
}

\begin{abstract}
This paper aims to develop a conceptual model that can assist managers in the development of competitive value chain using value co-creation and integration to make the whole supply chain competitive. The model is based on theoretical and conceptual underpinnings of value co-creation, network theory, value chain, and customer value theory. The model focuses on the idea that integrated value chains with high value co-creation abilities within them would make the whole supply chain competitive. That means that if the individual firms along the supply chain work on improving their value co-creation abilities, and they are well-integrated, it will increase the whole supply chain competitiveness. It is a conceptual model that needs to be operationalized and empirically tested in the future. The model suggests high value co-creation abilities in the individual value chains with a well-integrated supply chain as a basis for supply chain competitiveness. The model includes several theoretical and conceptual views related to value cocreation. However, it may be possible to add some additional perspectives in the future research.
\end{abstract}

Keywords: value chain, value co-creation, integration, supply chain competitiveness, supply chain performance

\section{INTRODUCTION}

Supply chain competitiveness (SCC) is a priority issue for firms to gain a competitive advantage, as it is an outcome of the integration of firms as well as it focuses on internal functional integration in firms. SCC is an important subject of interest as argued in many studies, (Segarra-Moliner et al. 2013; Lambert and Cooper 2000; Ketchen Jr and Hult 2007), with the view that competition and rivalry exist between competing supply chains rather than between firms on the basis of value creation for the customer. In recent years, there has been an increasing interest in the concept of supply chain integration to improve supply chain performance (SCP) and competitiveness (Ataseven and Nair 2017). SCC refers to the ability of the supply chain as a whole to be efficient and effective performing chain using firms' resources superior than other supply chains. It is the relative strength of supply chain needed to win in the competition
(Rajagopal 2010; Shang et al. 2010; Sahay et al. 2006; Verma and Seth 2011; Pace and Stephan 1996; Lambert and Cooper 2000; Verma and Seth 2010).

SCC is studied from many perspectives, like Pine (1999) used the standpoint of mass customization to explain SCC. La Londe and Powers (1993) explained the competitiveness of supply chain from the perspective of improved communication and information sharing within supply chain actors. From the perspective of operations strategies and operational effectiveness, the SCC has been studied extensively (Fisher, 1997; Fuller, O'Conor, \& Rawlinson, 1993; Simchi-Levi, 2008). Agility, flexibility, and responsiveness are necessary for SCC that are achievable through the collaboration of supply chain partners (La Londe and Powers 1993; Vokurka and Fliedner 1998). Superior performing competitive supply chain is also addressed with the logic of supply chain members' collaboration and supply chain synergy because of information sharing, joint decision making, sharing incentives and benefits to gain competence in supply chain (Wee and Wang 2013; Lorentz 2008; Anbanandam et al. 2011; Lehoux et al. 2010). In the same manner, the external and internal integration as the consequences of agile and lean supply chain strategy for the sake of SCC has also been an extensively studied area in the literature (Qi et al. 2017).

On the other hand, there is a gap in research as the SC systems have been studied in literature with the standpoint of whole chain performance rather than considering from the view of an individual firm's value chain as a building block of SC for SCC. The rationale is, that value is co-created and resides within the upstream and downstream firm value chains between the functions based on their individual capabilities and core competencies (Porter, 1991).

The supply chain needs to be studied from the perspective of value chains of supply chain partners because it is the integration of these idiosyncratic value chains that make up the whole supply chain. In other words, the core basis of supply chain systems lies in the individual firms' value chains when their primary and support functions interact, and resource integration is done. 
The proposition herewith is that if the value chain of a firm through its value co-creating functionalities (the outcome of inter-functional coordination), when combined with other similar partner value chains with higher value cocreating functionalities, will create an integrated supply chain that is competitive. The present study focuses on SCC using the perspective of value co-creation among functional units of the firm's value chain resting on the exposition of inter-functional coordination. This value co-creation is significant contributor where co-creation is the core value formulation underpinning the competitiveness of the value chain.

Competitiveness of individual value chain in this study is considered as the outcome of value co-creation process dependent on the inter-functional coordination. Therefore, the inter-functional coordination process of the firm incorporating the primary and support functions located within its boundary is the key to the SCC. In this study, the value co-creation process will be used as a conceptual twin to the process of inter-functional coordination. Therefore, a firm with a high level of inter-functional coordination will have higher intra-firm value co-creation ability.

This study is conducted with the reason that the theoretical gap exists while explaining the phenomena of SCC with the perspective of inter-functional coordination within the value chain to co-create value. This study is the early one that focuses on the development of a theoretical model by studying the relationship of value co-creation and SCC as a novice perspective in the context of supply chain management research and practice. The relationships of constructs in the model are new in the eclectic frame of customer value theory, network theory, and value chain perspective.

The integration of various competitive firms' value chains within a single supply chain using value co-creation perspective has not gained adequate attention. That gap in literature is discussed by Tokman and Beitelspacher (2011) who argued that there are gaps in research as well as integration of resources within firms is concerned with the perspective of value co-creation to improve performances.

This model is also contributing in a way that often the VCC has been studied in the context of firm and customer interaction however, interaction exists between other stakeholders as well such as between suppliers, producers, distributors and functions (procurement, logistics, operations, sales and marketing). In the current study functional interaction of firm is discussed who interact and co-create value for each other by co-working, coordination and collaboration. In that lieu, it has been argued that there are gaps in research as well as integration of resources within firm is concerned with the perspective of value co-creation (Tokman and Beitelspacher 2011). Moreover, in prior studies, inadequate attention has been given to co-creation processes at micro level during dyad or multi actor interaction. In literature, value co-creation studies emphasized on macro-perspectives and outcome rather than the co-creation activity itself. Therefore, this research contributes in both ways; by infusing value co-creation as a new perspective to create SCC and by advancing value cocreation conception at micro-level, when functional members interact and perform co-creation activities.

The remainder of this paper is structured as follows; to begin with, literature review of Network and coordination theory, inter-functional coordination, VCC, SCC, customer value theory, and value chain is presented in Section 2. In this section, the theoretical stance of network theory with implications in the SC actors' value chains and SC as a whole is presented. Then, to put emphasis on value creation within the firm's value chain the concept of inter-functional coordination is drawn from the antecedents of market orientation and internal marketing to link it with relationship quality and VCC. After that, value chain concept is described in relation to VCC between functions. Then at the last of this section, SCC, and customer value theory is described. In Section 3, the propositional model is presented. In Section 4, the theoretical propositions, managerial implications and future research directions are presented in the same section.

\section{CONCEPTUAL MODEL}

Conceptual model presents the value co-creation in the result of inter-functional coordination within the integrated firms' value chains as a source of superior performance of supply chain. It is argued that within individual firms' value chains by performing collaborative activities during interactions of functions, potential value is co-created. Supply Chain as a whole is constructed on individual firms' value chains as building blocks that perform well if they are strong and competitive due to higher value co-creation.

In more simple words, value will be co-created from the individual firm value chain as well as from the integrated firms' value chains from their respective interacting functions. Therefore, co-created value is an individual firm's value chain phenomenon and it emerges during interfunctional coordination, as shown in the Figure 1.

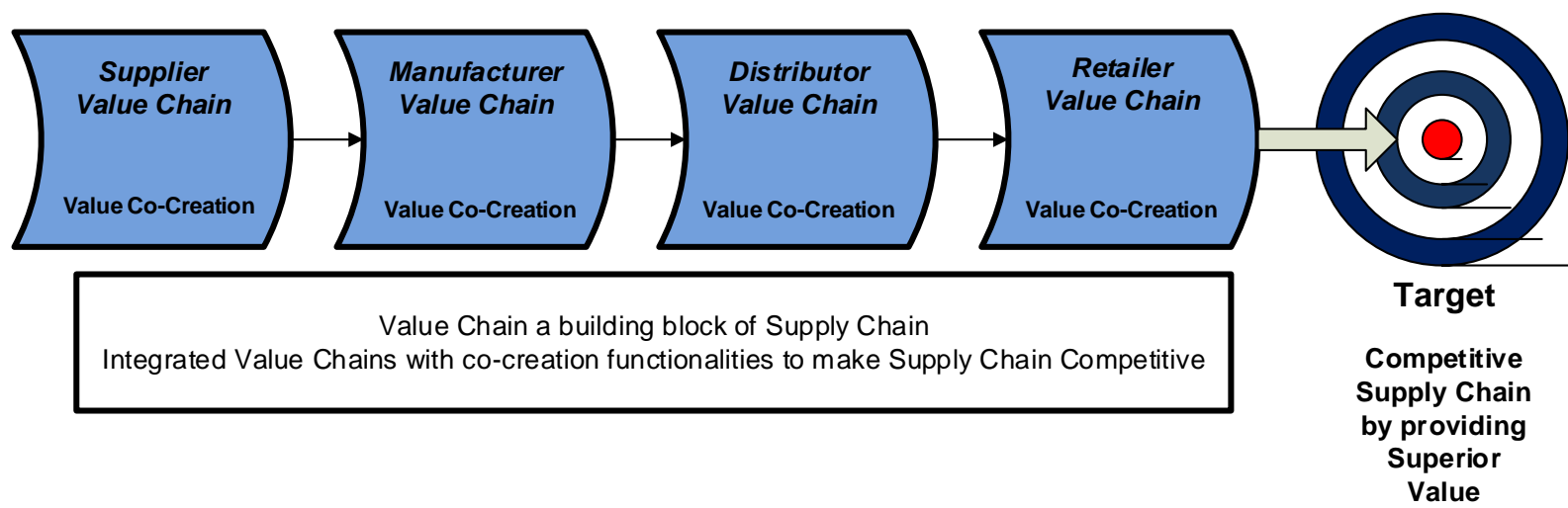

Figure 1 Integrated firm's value chains with value co-creation functionalities 
The conceptual model is built upon literature chronically, explaining from the conceptual and theoretical perspectives of network theory, coordination theory, market orientation, internal marketing and customer value theory.

\subsection{Network Theory}

Both perspectives of network and coordination theory provide a robust basis to explain the inter-functional coordination within the network of functions of the value chain to co-create value for each other and inter-firm integration within the network of supply chain partners. An ideal supply chain system demands better connectivity within the firms of supply chains and between the firms of supply chain by developing mechanisms of coordination and cooperative work environment. Therefore, superior SCP is advent when cooperative arrangements exist between firms of supply chain network. However, it is possible only when individual firms' network of functions is encouraged to put coordinated efforts. The integration of value chains with disconnected functions within them would rarely result in superior SCC.

The network theory implications explain clearly about the mission of SC management, as it is a form of a network between the SC members because network theory can explain the complex phenomena of interdependencies in chains consist of business entities (Ketchen Jr \& Hult, 2007). The concept of network refers to the strong and weak ties between two or more organizations (nodes). The network consists of nodes along with connections and ties between them. In a network web, some nodes are tied directly and indirectly, and a particular structure is developed in which different positions are occupied by the nodes (Borgatti \& Halgin, 2011). To maximize the SCC, the strong and weak ties can be strategically developed with other partners in the network that matches the needs of supply chain like reliability and flexibility (Granovetter, 1977). Weak ties are beneficial when flexibility is demanded and strong ties are better in the case of reliability (Ketchen Jr \& Hult, 2007).

Relationships among the members of supply chain, keeping in view the dynamics of whole supply chain are positively related to the drivers of the value supply chain and its performance. Networks are developed with relationships, for the sake of overall supply chain objectives with the vision of ultimate mutual profitability and competitiveness of all supply chain actors. In this view of networks, the nature, level, and type of relationships matter a lot. In the networks of firms, there can be many arrangements, for example, from loose knitted to strongly knitted, from arm's length bargains to total integration (Thorelli, 1986).

The main concern and strategic intent of supply chain management is the strategic focus on the co-operation, coordination, collaboration, trust, and other elements of networks. Christopher (2005) argues that the focus of supply chain is the relationship management to achieve profitable outcomes for the mutual benefits of all partners. It is argued categorically that the term of supply chain management may be changed with "demand network management," as demand refers to the notion of market-driven chain. In addition, network refers to the system of relationships with the suppliers' suppliers, suppliers, focal firm, distributors, wholesalers, and customers. It is argued that supply chain management should be defined as "A network of connected and interdependent organizations mutually and cooperatively working together to control, manage and improve the flow of materials and information from suppliers to end user."

\subsection{Coordination Theory}

The implications from coordination theory can be drawn for inter-functional coordination within the firm's value chain. Coordination theory (Cormack \& Smith, 2005; Crowston, 1997; Olson, Malone, \& Smith, 2001; Roh, Min, \& Hong, 2011) consists of principles that how the separate actors, can work together while performing activities in a coordinated way to achieve some common and shared goals in a cooperative manner. Functions can coordinate depending on the dependencies of their functional tasks on each other. Coordination involves the subdivision of tasks, assignment of tasks to actors, resource allocation to the actors, information sharing among actors. The functional dependencies probe coordination mechanisms and these dependencies are categorized into three sub-dependencies: 1) usability 2) transfer 3) and precedence. "Usability" means that the resource created by the first task is useful and appropriate for the second task. "Transfer" sub dependency means that the resource must be transferred from the point of origin to the point of consumption where the task will be performed. "Precedence" means that the second task performer must know and be informed about the resource when available and the task can be started.

\subsection{Market Orientation and Internal Marketing}

Now moving towards the conceptual base of interfunctional coordination, its conceptualization provides a foundation for co-creation activities between two or more functional departments because when functions coordinate during interaction, they share their unique capabilities, information, resources, and skills with each other to cocreate value to convert it into potential value for the customer.

Inter-functional coordination has been studied and discussed in market orientation and internal marketing literature extensively. In investigating market orientation with relation to business profitability (Narver and Slater 1990; Kohli and Jaworski 1990) it has been found that interfunctional coordination is a capability of the firm to create superior value with coordinated efforts by all the functions. Similarly, in the buyer's value chain, the contribution of seller firm's value chain to create superior value by integrating resources of all the functions is significant. The synergy is created in the result of orchestrated by the contribution of each sub-group of the firm tailored and integrated according to the requirement to serve buyers better with superior value. This contribution of functional members in inter-functional coordination can be taken as sharing of resources with each other and value is co-created by integrating and combining their resources to deliver it to the buyer to enhance its value in use.

The literature of internal marketing correspondingly emphasizes inter-functional coordination as a basis of customer satisfaction and improvement of business performance. Here, the enabler of inter-functional coordination to create value for the customer is internal customer satisfaction, that is, an employee working within 
the firm (Ahmed and Rafiq 2003; Kaur and Sharma 2015). Internal marketing emphasizes the breaking of silos between functions because no single function can be effective without the coordination of other functions. Internal Marketing involves the relationship development in networks of the functions in their interactions and interfaces within the internal supply chain (Ahmed and Rafiq 2003).

\subsection{Value Co-creation}

The co-creation of benefits and value by two or more actors, i.e. two or more functions of value chain firm is a phenomenon that makes them competitive and strong in terms of performance and unique ways of doing activities.

Value co-creation has usually been defined in literature with vague and unclear meanings especially when the concern is that how it is created, who is creating it and what are the roles of parties in value co-creation process because it cannot be considered as a one-time event. Service dominant logic literature has focused on the proposition that value is co-created as all exchanges between the two parties are service oriented and in the view of this study, between various functional departments of a value chain (Lusch et al. 2008; Vargo and Lusch 2004; Vargo and Lusch 2008).

The more clear definition and conceptualization which is taken up in this study is from the seminal work of Christian Gronroos who defined "value co-creation as the mutual benefit emerges in the result of experiences of interactions in interfaces between the parties" (Grönroos and Voima 2013; Grönroos 2012). It has been argued in these conceptual models that value co-creation is metaphor used in the literature to represent the view of value formation, independent value creation of parties, value in use and joint value creation during interactions. So, value co-creation as an expression represents many varied activities and actions that could be either independent or joint value creation.

Conceptual model of value co-creation (Figure 2) (Grönroos, 2012) is developed based on the early service marketing literature of the 1970s, which argues that second party (customer) creates value in the form of value in use, when he uses the service formed by provider and co-creation of value takes place when provider (one party) and customer (second party) interact. In this model, service concept is the value formed by the provider as an input, and there is a process regarded as a service process in which activities are performed by the interacting parties using physical resources. As an outcome of the service process, the experienced service emerges that is also a process in itself.

The service process between service concept and experienced service is a co-creation phase where interaction as a platform of value co-creation takes place. It has been argued that value has different forms like potential value that exists in the providers' sphere and plays the role of facilitator in value creation of beneficiary (value in use) as shown in Figure 3. The second sphere is a joint sphere where beneficiary or customer creates value by inviting provider as a co-creator to engage in his value creation processes during the interaction. The involvement of provider in the value creation process of customer during interaction enables cocreation. The third sphere is customer sphere where customer or beneficiary creates value for himself independently outside the interaction. It is also regarded as the value in use by using the resources he already has and the resources provided by the provider. Here the role of provider is again as a facilitator. Value in use is independent value creation by the customer by interacting with resources provided by the provider but do not interact with the process of the provider.

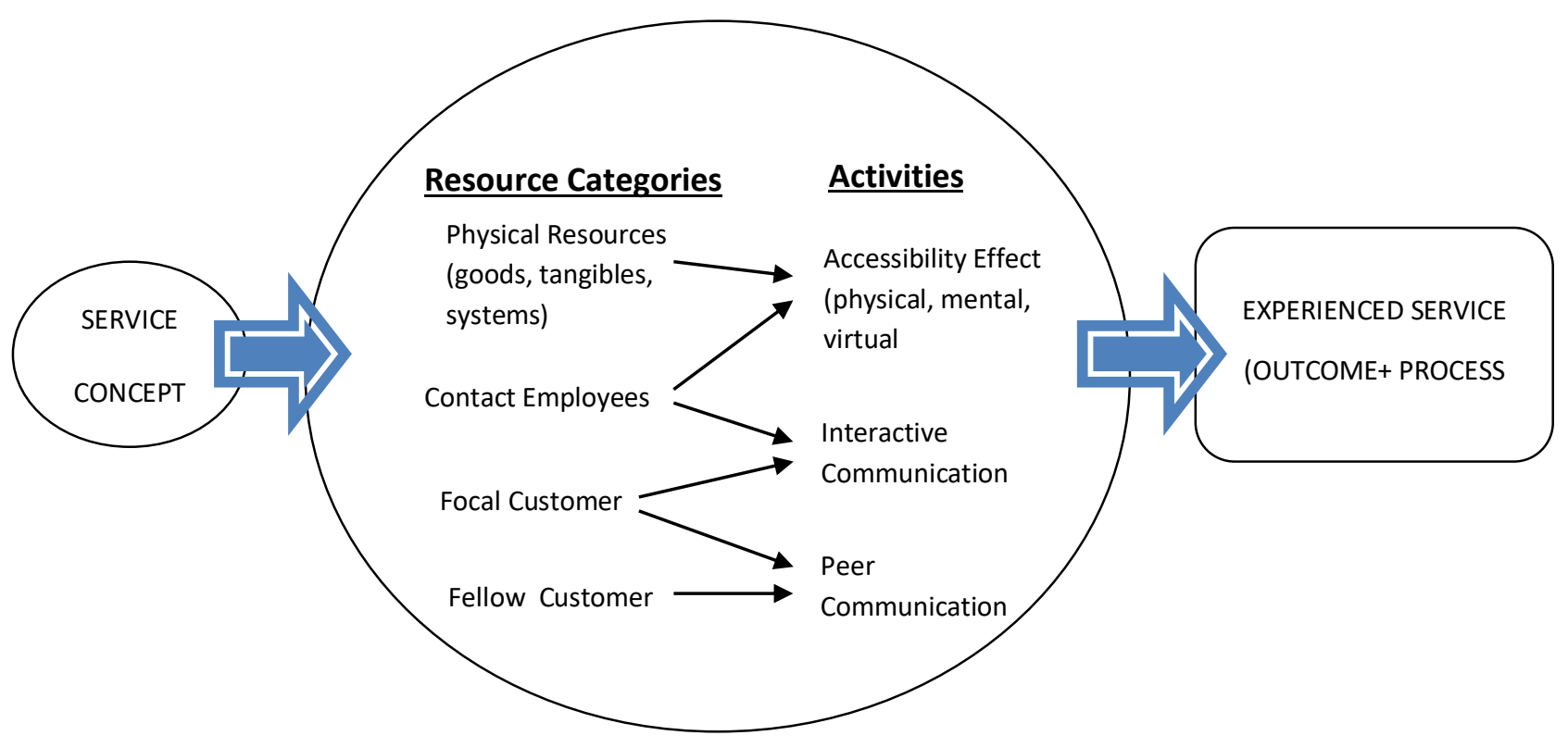

Figure 2 Conceptual model of value creation

(Grönroos, 2012) 


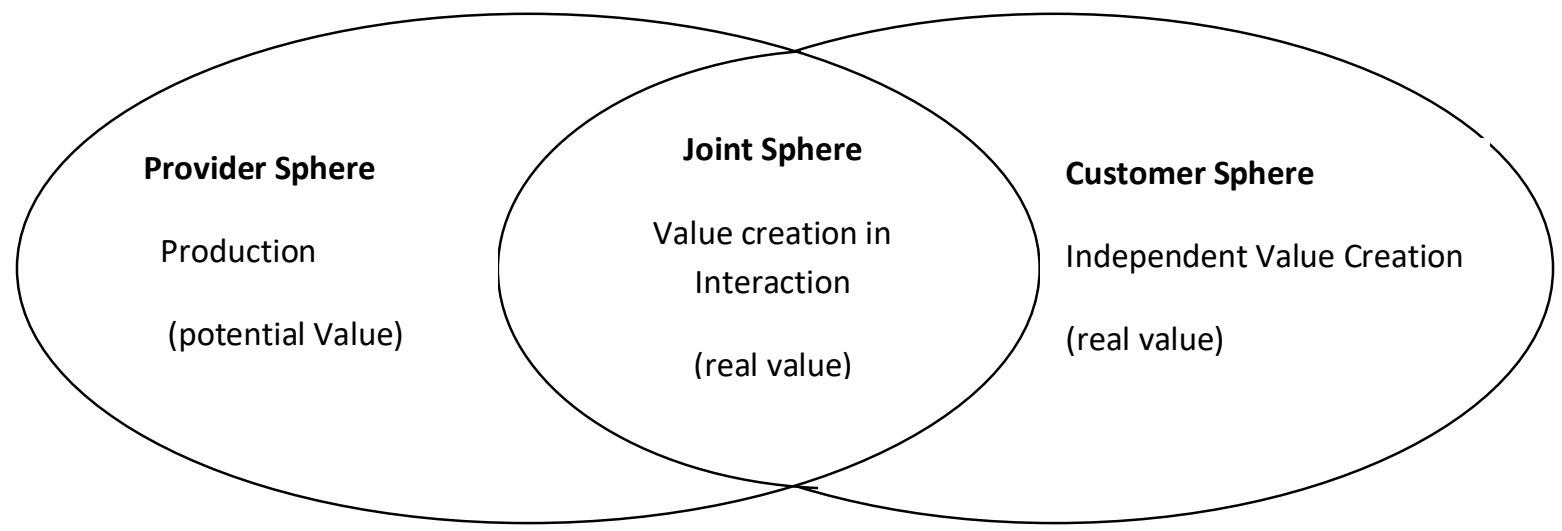

Figure 3 Value co-creation spheres (Grönroos and Voima, 2013)

Value co-creation transcending from metaphorical view studied empirically and analytically by measuring the extent to which it is being co-created by a validated scale of co-creation behavior (Yi \& Gong, 2013). This scale for measuring customer value co-creation has two main dimensions; customer participation and customer citizenship in terms of behaviors of customers called as customer participation behavior and citizenship behavior.

Another validated scale of VCC is developed by Ranjan $\&$ Read (2016). This scale has two higher order dimensions conceptualized as "Value Co-Production" and "Value in Use". Co-Production is the higher order construct of three more dimensions Knowledge Sharing, Equity, and Interaction. Value in Use (ViU) consists of Experience, Personalization, and Relationship.

\subsection{Value Chain}

The relationship quality generated within the networks of supply chain is directly linked with the value delivery to the end consumer. If the relationship quality is not higher within supply chain networks, it will not be possible to deliver value to end consumer. The implication of Michal porter's value chain is necessary to understand the premise of networks and relationships and cross-functional integration in the firm as well as between the partners of supply chain for the sake of value creation. Value chain perspective of the firm explains the phenomena of value creation out of a firm by Cross-functional activities and performances of primary and secondary functions (Porter 1991; Porter 1996; Porter 2008; Porter and Kramer 2006). It is argued that a firm is composed of discrete activities but inter-related to each other such as product manufacturing, logistics, selling, order booking, etc. Therefore, competitive advantage lies in the lower cost and differentiated way of doing these activities better than rivals do to create value and then deliver to end consumer.

The value generation by cross-functional integration to perform inter-related activities predicts customer value. The firm's strategy revolves around the performance measurement of inter-related activities in the firm as a critical success factor (Reitsma, Hilletofth, \& Mukhtar, 2018). These discrete activities are part of the interdependent system in which activities, and their efficiency and effectiveness are dependent on each other. The linkages between the activities are not just restricted to firm; they encompass the activities of suppliers, distributors, and customers as well. The end user value will be the outcome of upstream value, and downstream value creation by combining the distributors' value chain, the firm's value chain, and suppliers' value chain. Value chain activities can be categorized into two types: the primary activities and support activities. These activities are inter-related by cutting across the traditional functions of firms. Keeping in view the implications of network theory for supply chain networking and relationship building, and value chain perspective for the creation of value the relationship marketing cannot be ignored. Christopher, Payne, \& Ballantyne (2013) addressed the relationship strategy with the context of value creation within the functions and delivery to customer with the logic of coordination of external customers and collaboration within the internal firm. From this study, the implications for networks and relationships in supply chain activities for value creation and delivery can be drawn.

The context of service quality management within the firm and to deliver customer value comes here, as, Christopher et al. (2013) explains that customer service is not just the issue related to the firm and the relationships with external customer, whereas it is related to the downstream upstream relationships as well. Customer value is the outcome of relationship quality and value in the shape of services performance between the firm's functional members, between the external firms of the upstream and the downstream value chain. It is asserted that internal exchange processes between functions are necessary in achieving the unified goal of customer satisfaction and value. The focus is on internal marketing activities that emphasis on intriguing the employees as suppliers and customers. The coordination and collaboration can be done by addressing the concerns of service quality between the functional members of the organization at the individual exchange level. The joint efforts of working of cross-functional members are necessary for the creation of value among them and then connected to the customer value delivered to the customer.

\subsection{Supply chain competitiveness}

To understand the concept of SCC, it is necessary to conceptualize the definition of competitiveness. The competitiveness is the relative strength of an entity that is needed for competing against the direct and indirect 
competitors (Cho, 1998). In this view, competitiveness can be divided into three categories with respect to the unit entity like the competitiveness of nations, the competitiveness of firms, and competitiveness of industries.

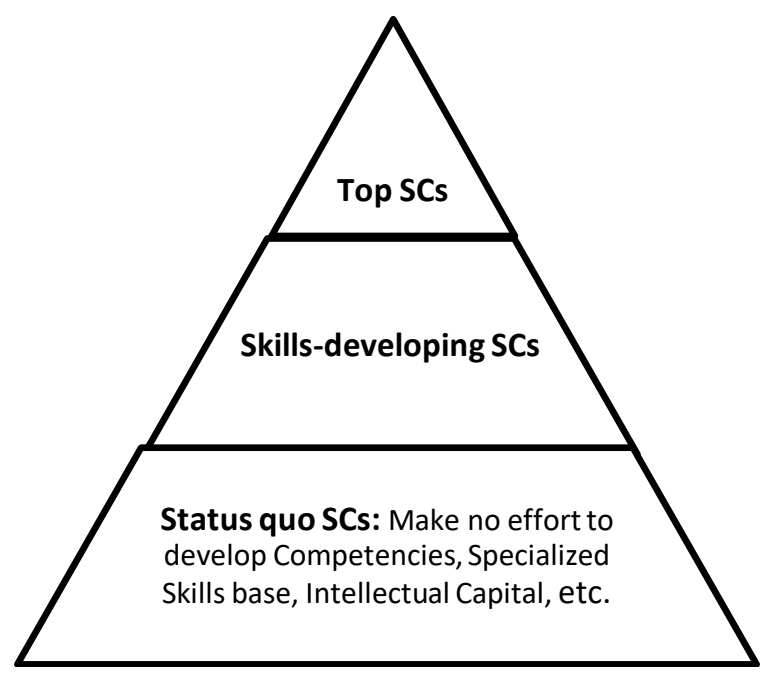

Figure 4 Supply Chain progression stages (Antai, 2011 p.85)

A clear definition of SCC is given by Antai (2011) explaining the difference between competitiveness and competitive advantage. A pyramid framework is developed in the study in which the stages of supply chains are described. Competitiveness is the preparatory stage for appearing in the competition as shown in Figure 4, the stage in which firms strive for the creation of competence, efficiencies, and effectiveness relative to the other supply chains. Competitiveness refers to the preparation for the competition by creating capabilities and competencies. On the other hand, competitive advantage is the advantage stage after sending the firm into competition. The supply chain provides superior customer value by leveraging resources as combining activities and resources create competitive advantage. Therefore, the creation of unique and sustainable capabilities and competencies are more probable to be created in supply chains when the internal functions of integrated value chains share their resources and skills. When value chains as building blocks of supply chain system gain strength, the whole supply chain performs well.

SCC is also defined as the efficient management of supply chain activities to deliver customer value (Jones and Riley 1985). Supply Chain activities deal with the total flow of material from suppliers to end customer. The three elements are proposed that constitute efficient supply chain, the detection of service level requirements of customers, the placement of inventory with the requirement of quantity along the whole supply chain, and the policies and procedures specification for the management of supply chain as a single integrated entity.

Competitiveness from supply chain management is taken as relative performance of supply chain with comparison to the competitors having necessary feature of inter-organizational as well as intra-organizational performance (Giménez and Ventura 2003). It is argued that a company's performance, keeping in view, the internal standardization like reduction of cost, lean processes, and lead-time reduction is the absolute performance. The variables identified in inter-organizational coordination consist of informal teamwork, shared ideas, information, other resources, established teamwork, joint planning to anticipate and resolve operative problems, joint establishment of objectives, joint development of the responsibilities' understanding, and joint decisions about ways to improve cost efficiencies.

The intra-organizational integration within the supply chain firms include informal teamwork, sharing information about sales, sales forecasts, stock levels, joint development of logistics processes, established work team for the implementation and development of continuous replenishment programs and joint planning to anticipate. It also entails resolving operational problems jointly, joint establishment of objectives, joint development of the responsibilities,' joint decisions about ways to improve cost efficiencies. Absolute performance composed of cost of serving, transportation cost, order processing cost, stock out reduction rate. Relative performance composed of responding to customer needs, satisfying special requirements, delivery rate, ordered quantities fulfillment, collaboration in new product launches, and prior intimation about inventory stock outs to customers (Giménez and Ventura 2003).

Competitiveness of a company is its strategic position in the market that is the outcome of operational efficiency using an efficient logistics system in place. It is the management flow of products and services to deliver value to customers in the whole supply chain (Bravo, Cortes, Aguilar, Granados, \& Amaya-Leal, 2007). The supply chain management strategy should be coherent with the overall business strategy (Sahay et al., 2006). Competitive advantage concept can be studied using different premises, the resource-based view, customer value theory, profitability of the firm, resource advantage theory, the comparative advantage theory.

Due to speedy technological innovations, globalization, widely used information technology, now, the SCC is necessary for firms to be the strategic focus. The strategic focus of supply chain demands to make alliances, reengineer, renovate, or refine the operations and develop strategies. SCC is composed of three components "suppliers" competitiveness," "manufacturer competitiveness" and "distributor competitiveness." SCC can be achieved by efficient delivery, customer satisfaction, better quality of products, profitability, better responsiveness, shorter lead times, demand fulfillment, optimal utilization of facilities (Verma and Seth 2010; Verma and Seth 2011).

Different researchers like Pine (1999) presented the perspective of mass customization to explain SCC. La Londe and Powers (1993) explain the competitiveness of supply chain with the perspective of improved communication and information sharing. With the perspective of operations strategies and operational effectiveness, Fuller et al. (1993) articulated about the tailored logistics concept to provide superior value to the customer.

Fisher (1997) argued about the best supply chain mode selection based on the nature of products; primary functional or primary innovative. Primary innovative nature of products like fashion products requires the supply chain process to be "market responsive," and primary functional nature of product requires the supply chain processes to be "physical efficient," (Basnet \& Seuring, 2014). Agility, flexibility, and 
responsiveness are necessary for SCC. They can be achieved with the collaboration of supply chain partners. The competitive strategic focus on mass production and cost saving by reducing unit cost has been changed. The competitive position based on the flexibility and agility in supply chain processes is the dominant strategic focus of the current era besides managing cost efficiency, quality management, and waste reduction.

The agility is defined as the capabilities to manufacture and market the variety of products having lower cost, higher quality, and lower lead times and with the features of flexible batch sizes to create value for the customer. The agility focus needs special attention for coordination and collaboration of the supply chain members (Vokurka and Fliedner 1998). SCC is also addressed with the logic of supply chain members' collaboration and supply chain synergy by information sharing, joint decision-making, sharing incentives, and benefits to gain supply chain competitive advantage (Anbanandam et al., 2011; Barratt, 2004; Lehoux et al., 2010; Lorentz, 2008).

To achieve the desired shared objectives of all supply chain members and SCC, it is necessary for members to collaborate and integrate the resources inside and outside their firm boundaries (Lorentz, 2008). The supply chain collaboration consists of some key enablers and variables including "top management commitment," "information sharing," "trust among supply chain members," "long term relationships," "risk and reward sharing," (Anbanandam et al., 2011). Supply chain collaboration has mainly two types; "vertical collaboration" and "horizontal collaboration."

The vertical collaboration includes the capability of supply chain partners to share resources and knowledge (Basnet \& Seuring, 2014) with suppliers, customers, and internal cross-functional collaboration. Collaboration is phenomena depending on the number of elements. There are some strategic elements like corporate focus, intraorganizational support, business case, and technology and some cultural elements such as openness and communication, information exchange, mutuality, and trust. These strategic and cultural dimensions make it possible to collaborate by intensifying collaboration culture of resource sharing and commitments to gain competitive advantage. Collaboration includes "joint decision making," "process alignment," and "cross-functional activities" (Barratt, 2004).

There are numerous studies available explaining supply chain practices, SCC, and SCP with the perspective of Quality Management and its constructs like customer satisfaction, leadership, management support, management commitment, customer focus, continuous improvement, supplier management, and employee involvement. Mentzer (2004) argued that it is not the product only that provides a competitive advantage, but it requires how the management of flow is performed within the supply chain. Howgego (2002) argued about the SCC with the logic of product management, supply chain flow management, supply chain synergy, and demand management.

Recently, agile supply chain strategy with the mediation of supply chain practice (strategic supplier partnership, customer relationship, and postponement) and moderating influence of information system capability is studied with relation to SCC (Tarafdar \& Qrunfleh, 2016). In the same way, the information sharing and collaborative work efforts are studied and found to have a positive impact on SCC (Wu, Chuang, \& Hsu, 2014). Authors while investigating SCP, found that two supply chain strategies lean and agile have a strong relationship with supply chain performance with moderating influence of two strategies related to information system - IS for efficiency and IS for flexibility (Qrunfleh \& Tarafdar, 2014). The lean, green, and resilient supply chain practices are examined in another study (Govindan, Azevedo, Carvalho, \& Cruz-Machado, 2015) that have a positive influence on SCP. As well as SCP measurement is concerned, there is a valid and reliable scale recently published used all types of performance measures available in literature so far (Gawankar, Kamble, \& Raut, 2016).

\subsection{Customer Value Theory}

The customer value theory (Slater, 1997) explains that firms survive in the industry by partnering and competing with other firms in the dynamic and heterogeneous market segments in a hyper-competitive environment. In this view of the firm, there are four fundamental notions taken into account. Firms strive for customer satisfaction by delivering value to the customers. In addition, the firms are considered to be the best if the focus is value driven offerings by understanding, addressing the specific needs of market segments and even individual customers using the dynamic capabilities and resources. Moreover, the firms having customer focused offerings are better able to attract the capital to enhance the scale and scope of the firm's activities. According to the theory superior performance of the firm is only possible if the firm is following the market orientation. Customer value theory clearly explains that process orientation and market orientation make the firm deliver superior customer value performance and gain a competitive advantage in the hyper-competitive markets. Acquiring, sharing, transfer, and application of customer knowledge increase the firms' competitiveness and chances to gain competitive advantage by exploiting their resources.

The customer value theory highlights a unique perspective of understanding the customer value known as the development of collaborative market intelligence capability by coordination and collaboration with suppliers, customers, and other partners (Slater, 1997). Customer value theory provides the fundamental holistic base for the competitive advantage, as, (Porter, 1985) explained that competitive advantage is gained if the firm can create value for its customers that exceeds the firm's cost of creating it. Similarly, the source of competitive advantage is value delivery to the buyers better than the competitors (Wilding and Newton 1996; Ma 2000; Mentzer 2004).

SCC is achieved by developing capabilities and competencies for delivering superior value delivery to the customer through supply chain better than other rival supply chains (Mentzer 2004; Bourlakis et al. 2012; Christopher 2005; Bhatnagar and Teo 2009; Porter 2008). Value is the notion that generates benefits for companies, customers, and shareholders. It influences the profitability and competitive advantage (Bourlakis et al., 2012).

The concept of value concerned with the relationships open the issues related to relationship types, development of network/s, interactions, co-ordinations, and collaborations to create the value within these interactions and encounters. Relationship quality is not just concerned with bi-lateral 
relationships but multi-actors' relationships in a network, at the whole supply chain level, to create value between them and then to deliver to end customer (Bourlakis et al. 2012; Lindgreen and Wynstra 2005). In this view, the value creation is the responsibility of all the supply chain members to create for the end consumer in the form of the value of final products and service offerings.

According to the global supply chain forum, supply chain management is the integration of business processes to provide value in the form of products, services, and information ranging from the original suppliers to the end consumers. So, the value plays a very important role for the firms to be able to gain competitive advantage (Lambert and Cooper 2000). The traditional supply chain is focused more on cost efficiencies, shorter lead-time, and lower cost and supply chain activities are taken into a linear form. Contrary to this view, value supply chain does not deal with only one aspect of supply chain properties like cost or agility. It is combination of drivers of value addition to the customer. The value supply chain focuses on all aspects of speed, flexibility, cost, and quality as the components of competitiveness for overall value creation for customers (Ketchen Jr and Hult, 2007).

\section{PROPOSITIONAL MODEL}

The capabilities, competencies, skills, and knowledge in performing activities on goods, materials, data residing in value chain creates competitiveness. In the same way, when value chains with value co-creating functionalities are combined, they ultimately become more competitive supply chain. During the interaction, functions with better interfunctional coordination create a synergy that will cause the altitudinous relationship quality among them. Superior relationship quality will create capabilities and competencies within the value chain to co-create value together with each other and higher co-creation of value will ultimately be the source of competitiveness for that individual value chain. Individual competitive value chains (units of supply chain) when integrate, cause the whole supply chain to be competitive (Figure 5).



Figure 5 Inter-functional Coordination within value chain to co-create value for SCC: Propositional Model

\section{CONCLUSION}

Inter-functional coordination in the interactions between the functions of the focal firm's value chain is a source of value co-creation and competitiveness individually for firm's value chain and broadly for the whole supply chain. Inter-functional co-creation creates synergy between functions of the value chain. Now, the answer to "why" interfunctional coordination creates synergy lies in the argument that interaction opportunities increases the probability of collaboration, coordination, strong relationships in the network and ultimately leads to value co-creation. Synergy, in the result of a strong relationship network creates the ability of actors to adopt the new ways of doing activities and create uniqueness that are not imitable. Concluding this study, conceived construct level propositions are elucidated that have strong theoretical implications and needed to be explored and investigated in future research.

\subsection{Theoretical Implications}

The theoretical propositions are presented below, drawn from the conceptual model of the study that is developed and based on the chronicle review and continuous discussion of the conceptual and theoretical premises in the above literature. The propositions explain the key constructs and their relationships.

Proposition 1: The Interaction between the primary and support functions of the firm's value chain enables synergy and inter-functional coordination and collaboration.

Interaction can be dyad, triad, or between many functions. Interaction is the first step toward coordination. The firms that are not market-oriented work in silos and are concerned with some performance parameters developed for themselves. Basically, they are concerned with those only and do not interact or have a rare interaction with other value creating functions. Although they are creating value for themselves but cannot get the benefit from value, the others can create for them, and they can create for other functions. Therefore, the more frequent and higher level of interaction can lead the functions and departments towards interfunctional coordination (Narver and Slater 1990; Kohli and Jaworski 1990) and synergy. Interaction enables interfunctional coordination because it has the higher chances of inter-departmental/functional connectedness, concern for others' ideas, trust, better information flows, and harmony. 
Instead, no or fewer interactions are there; the amity will not be the case.

Proposition 2: The inter-functional coordination will be a source of synergy and synergy will be a source of crossfunctional coordination reciprocally.

The synergetic situation is the situation when combining two parts yields amplified benefit than the individual parts could gather in silos (Chatterjee, 2007). Therefore, the benefit is multiplied many times. Better the synergy better will be the coordination among functions, and it will give the power to have more amplified benefit.

Proposition 3: The Inter-functional coordination and synergy enable the relationship quality to be higher among the primary and support functions with the value chain.

Relationship quality entails the commitment, trust, satisfaction, goal compatibility between two or more parties' relationships (Athanasopoulou, 2009). A study explored the dimensions of RQ (Relationship quality); information sharing, communication quality, long term relationship orientation, and relationship satisfaction (Lages, Lages, \& Lages, 2005). Therefore, inter-functional coordination and synergy enable better relationship quality because of better sharing of information related to processes, products, tasks, customers, materials, demands, situations, and circumstances. In the same vein, relationship quality will be higher because of the higher degree and quality of communication, long term relationships, and satisfaction towards each other.

Proposition 4: The relationship quality within the firm enables value co-creation among the functional partners and co-created value within an individual firm value chain.

The relationship is necessary to be developed in the result of inter-functional coordination. The degree of relationship quality will determine the co-created value. If the relationship quality is higher than it causes the co-created value to be higher. Value is also created independently by the functions using their individual resources but also co-created when there is inter-functional coordination and higher relationship quality during the interactions Relationship quality among the functions (procurement, production, marketing \& sales, inbound logistics etc.) due to the features of long term orientation, better information sharing, satisfaction, commitment, trust and goal compatibility, enable them for mutual benefit creation (Grönroos and Voima 2013; Grönroos 2012) in the result of experiences in interfaces between the parties.

Proposition 5: The value that is co-created by the functional members will result in competitiveness of individual value chain.

Value is a benefit that can be related to tasks and activities they are performing. Value emerges out by integrating the resources of all functions that are coordinating and have good relationship quality. Higher the value creation of functions for each other together they created by integrating unique or expert resources, the higher will be the competitiveness of the firm. Competitiveness refers to the preparation for the competition by creating capabilities and competencies for superior performance (Antai, 2011) and value (task value, or in other forms) have more chances to be created with greater magnitude if they are created jointly, i.e. co-created because different functions are expert in their areas with their own unique capabilities and competencies. For example, procurement is expert in vendor evaluation and selection, while production is expert in producing goods and joint resources, knowledge, capabilities, and, skills sharing of both functions can be utilized by both functions to perform their tasks better.

Proposition 6: The integration of individually competitive value chains of supply chain will result into the whole SCC.

The SCC is a function of integration of individual best performing competitive value chains having strong interfunctional coordination and co-created value. The integration of upstream and downstream value chains to make up the superior customer value from the whole supply chain (SSC) has been implicitly explained by value chain conceptual underpinnings (Porter, 1991). Therefore, the need is to make individual units strong and it is necessary to strengthen them by co-creation of value for all the interacting parties, so that, their performance is likely to be better because ultimately value is residing within value chains created by unique capabilities and skills of functions.

Proposition 7: The competitive supply chain as the best performing chain as compared to competing supply chains will result in the delivery of superior potential value to the customer.

The superior value for external customer emerging out of supply chain depends on the higher value creation by the functions of value chains and ultimately for the customer. The creation of potential value for the end customer is based on customer centricity visualizing customer needs (Slater, 1997 ) in the processes of individual partners' value chains of the supply chain. The reason is that the combined and integrated superior performances of upstream and downstream value chains with customer focus that become SCC will create potential value for end customer.

\subsection{Managerial Implications}

From a practical and managerial standpoint, the proposed theoretical implications should lead to the more efficient and effective management of SCP with the view of value co-creation for the value chain functions and the end customer in the form of potential value. The implications can also suggest the practitioners and strategists to device cocreation strategies within their firms between functions by enabling inter-functional coordination and relationship quality among them in their value chains so that they can enable the network of these value chains to be competitive in an integrated manner that would result in the competitiveness of the supply chain. Therefore, value co-creation within their value chains is the key to gain the competitiveness for supply chains. One of the examples of the significance of the cocreation is IKEA, a Swedish firm, who invited the customers to design their furniture on their own and utilize their skills with the help of IKEA extensive product assembly catalogues. Using this strategy, IKEA and customers both got better value.

In the same way, co-creation between functions of value chains, functions can gain value from each other that would be beneficial for them and the whole supply chains as 
well. The value creation by functions within firms' value chains in the result of inter-functional coordination would make it possible for supply chain to be more market oriented and responsive to the needs of markets. Similarly, agility (Khan \& Wisner, 2019), responsiveness, flexibility, quality assurance, cost efficiency, of the supply chain would be possible to transform into firm performance if the functional integration and value co-creation within the value chains and their comes into action.

\subsection{Future Research Implications}

This conceptual paper argues that in the result of the interaction of value chains functions, co-created value for each other and it is a source of higher competitiveness for value chain and when these higher value co-creating value chains are integrated, it is a source of competitiveness for the whole supply chain. The theoretical model presented is built upon the literature review of different theoretical and conceptual underpinnings. There is no study without any limitations. The conceptual model consists of constructs developed at an abstract level needed to be operationalized at variable level, tested and generalized based on the same or other theoretical underpinnings using empirical investigation. There can be a future study by exploring and confirming the dimensions of VCC within the context of inter-functional interaction within the firm and between the firms of supply chain.

\section{REFERENCES}

Ahmed, P. K., \& Rafiq, M. (2003). Internal marketing issues and challenges. European Journal of Marketing, 37(9), pp.11771186.

Anbanandam, R., Banwet, D. K., \& Shankar, R. (2011). Evaluation of supply chain collaboration: a case of apparel retail industry in India. International Journal of Productivity and Performance Management, 60(2), pp.82-98.

Antai, I. (2011). A Theory of the Competing Supply Chain: Alternatives for Development. International Business Research, 4(1), pp.74-85.

Ataseven, C., \& Nair, A. (2017). Assessment of supply chain integration and performance relationships: A meta-analytic investigation of the literature. International Journal of Production Economics, 185, pp.252-265.

Athanasopoulou, P. (2009). Relationship quality: a critical literature review and research agenda. European Journal of Marketing, 43(5/6), pp.583-610.

Barratt, M. (2004). Understanding the meaning of collaboration in the supply chain. Supply Chain Management: An International Journal, 9(1), pp.30-42.

Basnet, C., \& Seuring, S. (2014). Demand-Oriented Supply Chain Strategies - A Review of the Literature. Operations and Supply Chain Management: An International Journal, 9(2), pp.73-89.

Bhatnagar, R., \& Teo, C.-C. (2009). Role of logistics in enhancing competitive advantage: A value chain framework for global supply chains. International Journal of Physical Distribution \& Logistics Management, 39(3), pp.202-226.

Borgatti, S. P., \& Halgin, D. S. (2011). On Network Theory. Organization Science, 22(5), pp.1168-1181.

Bourlakis, M., Maglaras, G., \& Fotopoulos, C. (2012). Creating a "best value supply chain"? Empirical evidence from the Greek food chain. International Journal of Logistics Management, 23(3), pp.360-382.

Bravo, B., Cortes, K., Aguilar, M., Granados, S., \& Amaya-Leal, J. (2007). Competitiveness in the supply chain management: An overview in an oils' and greases' manufacturer. Ingeniería y Desarrollo, (22), pp.38-53.

Chatterjee, S. (2007). Why is synergy so difficult in mergers of related businesses? Strategy \& Leadership, 35(2), pp.46-52.

Cho, D. S. (1998). From national competitiveness to bloc and global competitiveness. Competitiveness Review: An International Business Journal, 8(1), pp.11-23.

Christopher, M. (2005). Logistics and supply chain management: creating value-adding networks. Pearson education.

Christopher, M., Payne, A., \& Ballantyne, D. (2013). Relationship Marketing. Routledge.

Cormack, A., \& Smith, N. (2005). What is coordination? Lingua, 115(4), pp.395-418.

Crowston, K. (1997). A coordination theory approach to organizational process design. Organization Science, 8(2), pp.157-175.

Fisher, M. L. (1997). What is the right supply chain for your product? Harvard Business Review, 75, pp.105-117.

Fuller, J. B., O'Conor, J., \& Rawlinson, R. (1993). Tailored logistics: the next advantage. Harvard Business Review, 71(3), pp.87-98.

Gawankar, S., Kamble, S., \& Raut, R. (2016). Development, measurement and validation of supply chain performance measurement (SCPM) scale in Indian retail sector. Benchmarking, 23(1), pp.25-60.

Gimenez, C., \& Ventura, E. (2003). Supply chain management as a competitive advantage in the Spanish grocery sector. The International Journal of Logistics Management, 14(1), pp.7788.

Govindan, K., Azevedo, S. G., Carvalho, H., \& Cruz-Machado, V. (2015). Lean, green and resilient practices influence on supply chain performance: interpretive structural modeling approach. International Journal of Environmental Science and Technology, 12(1), pp.15-34.

Granovetter, M. S. (1977). The strength of weak ties. In Social networks (pp. 347-367). Academic Press.

Grönroos, C. (2012). Conceptualising value co-creation: A journey to the 1970 s and back to the future. Journal of Marketing Management, 28(13-14), pp.1520-1534.

Grönroos, C., \& Voima, P. (2013). Critical service logic: Making sense of value creation and co-creation. Journal of the Academy of Marketing Science, 41(2), pp.133-150.

Howgego, C. (2002). Maximising competitiveness through the supply chain. International Journal of Retail \& Distribution Management, 30(12), pp.603-605.

Jones, T. C., \& Riley, D. W. (1985). Using inventory for competitive advantage through supply chain management. International Journal of Physical Distribution \& Logistics Management, 15(5), pp.16-26.

Kaur, J., \& Sharma, S. K. (2015). Internal marketing: Scale development and validation. Vision, 19(3), pp.236-247.

Ketchen Jr, D. J., \& Hult, G. T. M. (2007). Bridging organization theory and supply chain management: the case of best value supply chains. Journal of Operations Management, 25(2), pp.573-580.

Khan, H., \& Wisner, J. D. (2019). Supply Chain Integration, Learning, and Agility: Effects on Performance. Operations and Supply Chain Management: An International Journal, 12(1), pp.14-23.

Kohli, A. K., \& Jaworski, B. J. (1990). Market orientation: The construct, research propositions, and managerial implications. Journal of Marketing, 54(2), pp.1-18.

La Londe, B. J., \& Powers, R. F. (1993). Disintegration and reintegration: logistics of the twenty-first century. International Journal of Logistics Management, The, 4(2), pp.1-12.

Lages, C., Lages, C. R., \& Lages, L. F. (2005). The RELQUAL scale: A measure of relationship quality in export market ventures. Journal of Business Research, 58(8), pp.10401048.

Lambert, D. M., \& Cooper, M. C. (2000). Issues in supply chain 
management. Industrial Marketing Management, 29(1), pp.65-83.

Lehoux, N., D'Amours, S., \& Langevin, A. (2010). A win-win collaboration approach for a two-echelon supply chain: a case study in the pulp and paper industry. European Journal of Industrial Engineering, 4(4), pp.493-514.

Lindgreen, A., \& Wynstra, F. (2005). Value in business markets: what do we know? Where are we going? Industrial Marketing Management, 34(7), pp.732-748.

Lorentz, H. (2008). Collaboration in Finnish-Russian supply chains: effects on performance and the role of experience. Baltic Journal of Management, 3(3), pp.246-265.

Lusch, R. F., Vargo, S. L., \& Wessels, G. (2008). Toward a conceptual foundation for service science: Contributions from service-dominant logic. IBM Systems Journal, 47(1), pp.5-14.

Ma, H. (2000). Competitive advantage and firm performance. Competitiveness Review: An International Business Journal, 10(2), pp.15-32.

Mentzer, J. T. (2004). Fundamentals of supply chain management: Twelve drivers of competitive advantage. Sage Publications.

Narver, J. C., \& Slater, S. F. (1990). The effect of a market orientation on business profitability. Journal of Marketing, 54(4), pp.20-35.

Olson, G. M., Malone, T. W., \& Smith, J. B. (2013). Coordination Theory And Collaboration Technology. Psychology Press.

Wayne Pace, R., \& Stephan, E. G. (1996). Paradigms of competitiveness. Competitiveness Review: An International Business Journal, 6(1), pp.8-13.

Pine, B. J. (1999). Mass Customization: The New Frontier In Business Competition. Harvard Business Press.

Porter, M. E., \& Advantage, C. (1985). Creating and sustaining superior performance. Competitive Advantage, pp.167.

Porter, M. E. (1991). Towards a dynamic theory of strategy. Strategic Management Journal, 12(S2), pp.95-117.

Porter, M. E. (1996). What is Strategy? Harvard Business Review, 74(6), pp.61-78.

Porter, M. E., \& Kramer, M. R. (2006). Strategy and Sosciety, The Link Between Competitive Advantage and Corporate Social Responsibility. Harvard Business Review, 85(12), pp.139139

Qi, Yinan, Baofeng Huo, Zhiqiang Wang, and H. Y. J. Y. (2017). The impact of operations and supply chain strategies on integration and performance. International Journal of Production Economics, 185, pp.162-174.

Qrunfleh, S., \& Tarafdar, M. (2014). Supply chain information systems strategy: Impacts on supply chain performance and firm performance. International Journal of Production Economics, 147, pp.340-350.

Rajagopal, A. (2010). Impact of quality programs on supply chain performance. Global Management Review, 4(3), pp.1-14

Reitsma, E., Hilletofth, P., \& Mukhtar, U. (2018). Enterprise Resource Planning System Implementation: A User Perspective. Operations and Supply Chain Management: An International Journal, 11(3), pp.110-117.

Roh, J. J., Min, H., \& Hong, P. (2011). A co-ordination theory approach to restructuring the supply chain: an empirical study from the focal company perspective. International Journal of Production Research, 49(15), pp.4517-4541.

Sahay, B. S., Gupta, J. N. D., \& Mohan, R. (2006). Managing supply chains for competitiveness: the Indian scenario.
Supply Chain Management: An International Journal, 11(1), pp.15-24.

Segarra-Moliner, J.-R., Moliner-Tena, M.-A., \& Sánchez-Garcia, J. (2013). Relationship quality in business to business: a crosscultural perspective from universities. Marketing Intelligence \& Planning, 31(3), pp.196-215.

Shang, K. H., Zhou, S. X., \& van Houtum, G.-J. (2010). Improving supply chain performance: Real-time demand information and flexible deliveries. Manufacturing \& Service Operations Management, 12(3), pp.430-448.

Simchi-Levi, D. (2008). Designing And Managing The Supply Chain Concepts Strategies And Case Studies. Tata McGrawHill Education.

Slater, S. F. (1997). Developing a customer value-based theory of the firm. Journal of the Academy of Marketing Science, 25(2), pp.162-167.

Tarafdar, M., \& Qrunfleh, S. (2017). Agile supply chain strategy and supply chain performance: complementary roles of supply chain practices and information systems capability for agility. International Journal of Production Research, 55(4), pp.925-938.

Thorelli, H. B. (1986). Networks: between markets and hierarchies. Strategic Management Journal, 7(1), pp.37-51.

Tokman, M., \& Beitelspacher, L. S. (2011). Supply chain networks and service-dominant logic: suggestions for future research. International Journal of Physical Distribution \& Logistics Management, 41(7), pp.717-726.

Vargo, S. L., \& Lusch, R. F. (2004). Evolving to a new dominant logic for marketing. Journal of Marketing, 68(1), pp.1-17.

Vargo, S. L., \& Lusch, R. F. (2008). Service-dominant logic: continuing the evolution. Journal of the Academy of Marketing Science, 36(1), pp.1-10.

Vargo, S. L., \& Lusch, R. F. (2014). Service-dominant logic: What it is, what it is not, what it might be. In The service-dominant logic of marketing (pp. 61-74). Routledge.

Verma, A., \& Seth, N. (2010). Achieving supply chain competitiveness: Some critical issues. International Journal of Science Engineering and Technology, 2(11), pp.62096213.

Verma, A., \& Seth, N. (2011). A conceptual framework for supply chain competitiveness. International Journal of Human and Social Sciences, 6(1), pp.5-10.

Vokurka, R. J., \& Fliedner, G. (1998). The journey toward agility. Industrial Management \& Data Systems, 98(4), pp.165-171.

Wee, H., \& Wang, W. (2013). Supply chain coordination for shortlife-cycle products with option contract and partial backorders. European Journal of Industrial Engineering, 7(1), pp.78-99.

Wilding, R. D., \& Newton, J. M. (1996). Enabling time-based strategy through logistics-using time to competitive advantage. Logistics Information Management, 9(1), pp.3238.

Wu, I. L., Chuang, C. H., \& Hsu, C. H. (2014). Information sharing and collaborative behaviors in enabling supply chain performance: A social exchange perspective. International Journal of Production Economics, 148, pp.122-132.

Yi, Y., \& Gong, T. (2013). Customer value co-creation behavior: Scale development and validation. Journal of Business Research, 66(9), pp.1279-1284..

Umer Mukhtar has industrial and academic experience spans over more than 7 years. Moreover, his research work has been published in reputed international journals like Journal of Knolwedge Management, Operations and Supply Chain Management: An International Journal. He has also earned opportunities to present his research work in international conferences in Australia, Russia, and Thailand. His research agenda consist of Supply Chain Management, Knolwedge Manageement, Ditribution Management, Marketing, and Quality Management. 
Tashfeen M. Azhar earned his Ph.D. in Industrial and Management Systems Engineering with a focus on Production Planning and Control, Fuzzy Mathematical Modeling, Computer Simulation, and Expert Systems from University of South Florida, U.S.A. Earlier he got his M.S. in Metallurgical Engineering and Material Sciences from University of Pittsburgh, U.S.A. and B.Sc. (Engg) in Metallurgical and Material Sciences from University of the Punjab, Pakistan. He has vast corporate experience in Operations and Supply Chain Management. His industrial and academic experience spans over more than three decades. He has served in the faculties of some of the leading business schools in Lahore. Moreover, his research work has been published in internationally recognized journals. 